\title{
Water-Level Altitudes in Wells Completed in the Jasper Aquifer, Greater Houston Area, Texas, Spring 2000
}

\section{Introduction}

This report, prepared in cooperation with the Harris-Galveston Coastal Subsidence District, presents a map showing the approximate water-level altitudes in spring 2000 in wells completed in the Jasper aquifer (back of page). The most recent previously published water-level-altitude map for the Jasper aquifer in the region is by Popkin (1971). The study area includes Montgomery County and parts of Harris, Waller, Grimes, and Walker Counties.

\section{Geohydrology}

The Jasper aquifer (in sediments of Miocene age) is the lowermost of the three aquifers of the Gulf Coast aquifer system in the greater Houston area. The Jasper aquifer is overlain by the Burkeville confining unit (in sediments of Miocene age), which in turn is overlain by the Evangeline aquifer (in sediments of Miocene and Pliocene age) and the Chicot aquifer (in sediments of Pleistocene and Holocene age). The hydrogeologic units dip from land surface southeastward at slight angles toward the Gulf of Mexico. The units thus crop out in bands approximately parallel to the coast. The Jasper aquifer outcrop, in the relatively oldest sediments, is the farthest inland of the hydrogeologic-unit outcrops. The Jasper aquifer in the greater Houston area thickens toward the coast from about 600 feet in the outcrop to about 1,000 feet at the base of fresh (less than 1,000 milligrams per liter dissolved solids) to slightly saline $(1,000-3,000$ milligrams per liter dissolved solids) water (Baker, 1979). The Jasper aquifer can be separated into two parts on the basis of lithology (Popkin, 1971). The upper part, which composes 50 to 80 percent of the aquifer, consists of a massive sand; the lower part consists mostly of interbedded sand and clay. In the natural system, water recharges the Jasper aquifer in its outcrop, gradually moves downdip and discharges upward through the Burkeville confining unit.

\section{Water-Level Measurements}

Water-level measurements used to prepare this map were obtained by steel tape, airline, and from reports by well operators. Most wells are pumped once daily, but some are pumped more frequently. Multiple measurements were made when wells were not being pumped. However, antecedent pumping conditions were not always known. Water-level measurements were made in the spring, when water levels usually are highest. The wells selected for water-level measurements had comparable depths and screened intervals.

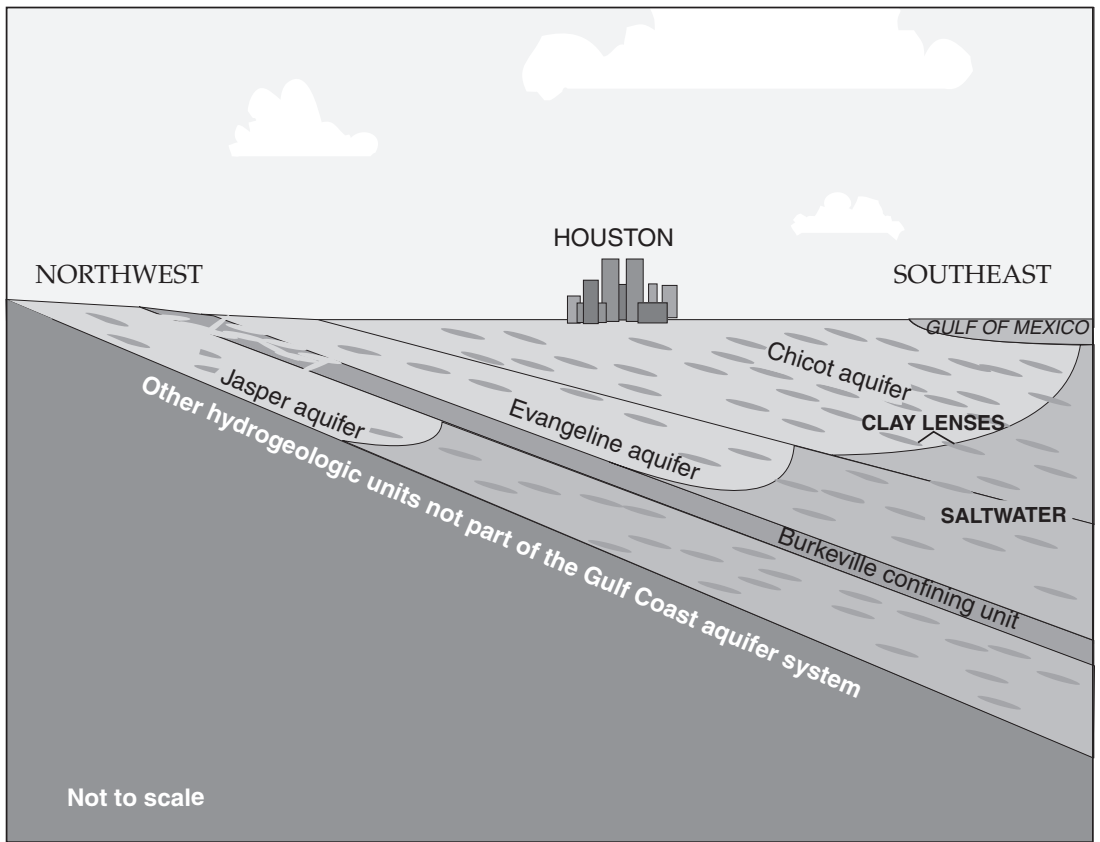

Generalized section showing the relation between the Chicot, Evangeline, and Jasper aquifers in the greater Houston area, Texas.

\section{References}

Baker, E.T., Jr., 1979, Stratigraphic and hydrogeologic framework of part of the Coastal Plain of Texas: Texas Department of Water Resources Report 236, 43 p.

1986, Hydrology of the Jasper aquifer in the southeast Texas Coastal Plain: Texas Water Development Board Report 295, 64 p.

Popkin, B.P., 1971, Ground-water resources of Montgomery County, Texas: Texas Water Development Board Report 136, 149 p.

\section{- L.S. Coplin}

For more information, please contact:
Subdistrict Office

U.S. Geological Survey 2320 LaBranch St., Rm. 1112

Houston, TX 77004
Phone: (713) 718-3655 FAX: (713) 718-3661

World Wide Web:

http://tx.usgs.gov/ 


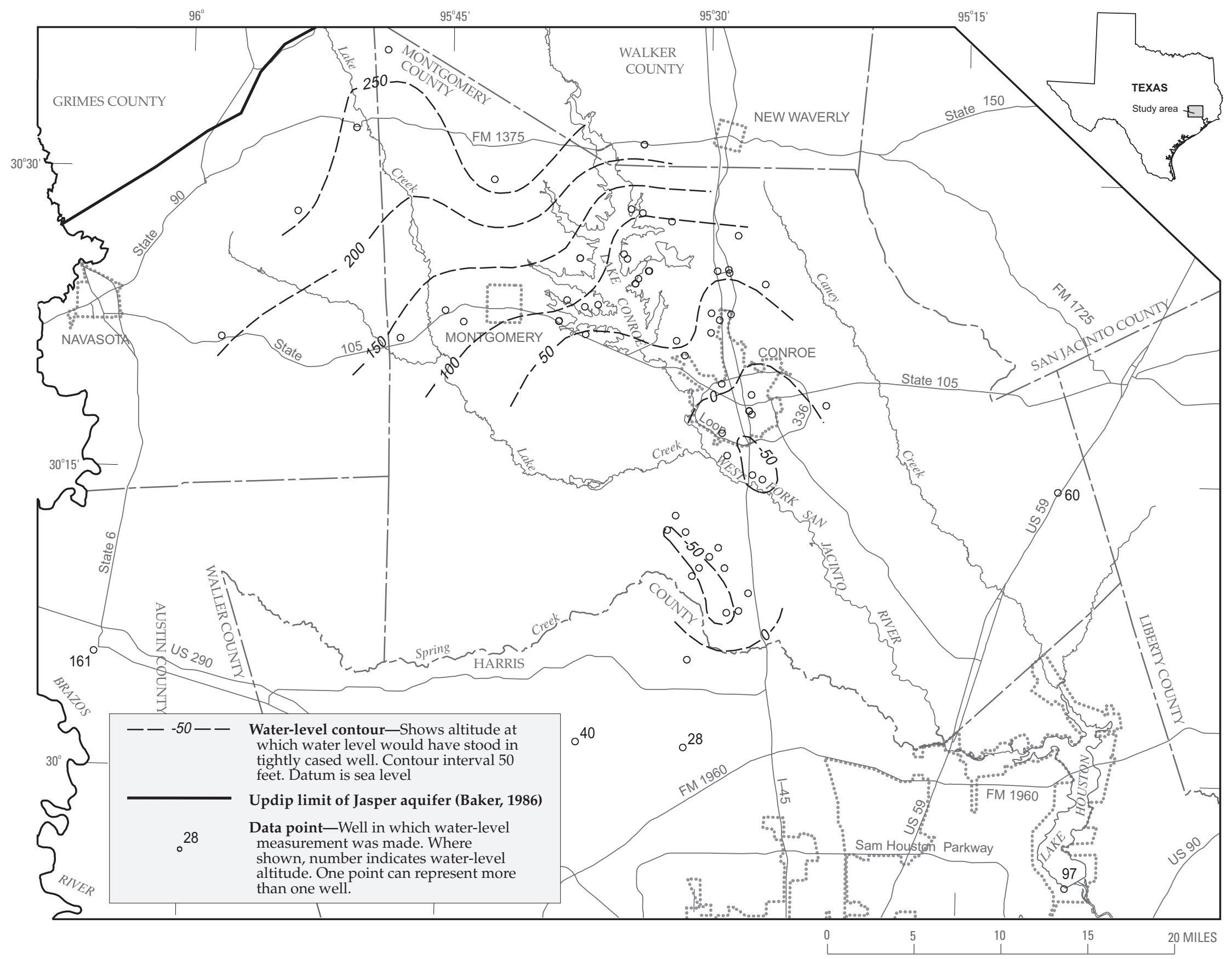

Approximate water-level altitudes in the Jasper aquifer, greater Houston area, Texas, spring 2000. 